\title{
TAX DEDUCTIBLE SEBAGAI KOMPENSASI KEGIATAN SOCIAL RESPONSIBILITY LEMBAGA NOTARIS DALAM PENGESAHAN BADAN HUKUM YAYASAN PONDOK PESANTREN
}

\section{TAX DEDUCTIBLE AS COMPENSATION OF NOTARY SOCIAL RESPONSIBILITY ACTIVITIES ON LEGITIMATION OF ISLAMIC BOARDING SCHOOL'S FOUNDATION}

\author{
Putri Echatarina dan \\ Martin Roestamy
}

\author{
Program Studi Ilmu Hukum Sekolah Pascasarjana \\ Universitas Djuanda Bogor \\ Jl. Tol Ciawi No. 1, Kotak Pos 35, Bogor 16720. \\ Korespondensi : Putri Echatarina, Telp. - \\ e-mail : -
}

Jurnal Living Law, Vol. 10, No.

1 ,

2018

hlm. 23-44

\begin{abstract}
The Foundation is a body that perform various non commercial activities (non-profit) and engaged in social, religious or educational one boarding school. Boarding School can be said to have a role as well as educate the nation's children because schools have a main function of the students can study and master the knowledge of Islam more deeply. Identification of this research are: 1) How is social responsibility in implementing the notary profession and professional public service to educational institutions and religious boarding school? 2) How is the implementation of income tax from the practice of social responsibility in relation to the obligation to pay income tax on any notary deed? 3) Are there policies about tax deductible to the practice of social responsibility that does not charge the notary deed or honorarium from clients who set up a foundation online boarding school?. The method used in this research is normative juridical approach, the law conceived as norms, rules, principles or dogmas/jurisprudence.
\end{abstract}

Keywords : Tax Deductible, Social Responsibility, Notary Public.

\begin{abstract}
Abstrak : Yayasan merupakan suatu badan yang melakukan berbagai kegiatan bersifat non komersial (nirlaba) dan bergerak di bidang sosial, keagamaan atau pendidikan salah satunya pondok pesantren. Pesantren memiliki peran dalam mencerdaskan bangsa karena pesantren memiliki fungsi utama yaitu mempelajari dan mengkaji ilmu agama Islam. Identifikasi penelitian ini yaitu: 1) Bagaimana social responsibility profesi notaris dalam menerapkan pelayanan publik dan profesional terhadap lembaga pendidikan dan keagamaan pondok pesantren? 2) Bagaimana pelaksanaan pajak penghasilan dari praktek social responsibility tersebut jika dihubungkan dengan kewajiban pembayaran pajak penghasilan dari setiap pembuatan akta notaris? 3) Apa ada kebijakan-kebijakan tentang tax deductible terhadap praktek social responsibility notaris yang tidak memungut biaya akta atau honorarium dari klien yang mendirikan yayasan pondok pesantren secara online?. Metode penelitian yang digunakan dalam penelitian ini adalah pendekatan yuridis normatif.
\end{abstract}

Kata Kunci : Tax Deductible, Social Responsibility, Lembaga Notaris. 


\section{PENDAHULUAN}

Yayasan merupakan suatu badan yang melakukan berbagai kegiatan bersifat non komersial (nirlaba) dan bergerak di bidang sosial, keagamaan atau pendidikan. Pada ketentuan Pasal 1 angka 1 Undang-undang Nomor 16 Tahun 2001 jo. Undang-undang Nomor 28 Tahun 2004 tentang Yayasan (yang selanjutnya disebut UU Yayasan) dinyatakan yayasan adalah badan hukum, yang terdiri atas suatu kekayaan yang dipisahkan juga diperuntukkan untuk mencapai tujuan tertentu dalam bidang sosial, keagamaan, dan kemanusiaan, yang tidak mempunyai anggota. ${ }^{1}$

Yayasan adalah suatu badan hukum yang terdiri dari harta kekayaan yang dipisahkan, maksudnya yayasan sebagai suatu badan hukum memiliki kekayaan yang dipisahkan dari kekayaan pengurusnya, jadi dengan kata lain yayasan mempunyai harta kekayaan sendiri. Harta kekayaan digunakan untuk kepentingan tercapainya tujuan yayasan. Hal ini sejalan bersama teori Brinz, bahwa harta kekayaan badan hukum terikat oleh suatu tujuan ${ }^{2}$.

Adapun kegiatan beberapa yayasan di Negara Indonesia diantaranya memberikan santunan kepada anak yatim piatu, memberikan kesejahteraan pada penderita cacat badan, memberikan beasiswa pada anak yang kurang/tidak mampu, memberikan bantuan pada keluarga yang sedang berduka, membantu memberikan pelayanan kesehatan kepada penderita suatu penyakit ${ }^{3}$. Tujuan yayasan bisa diarahkan kepada pencapaian sesuatu di lapangan kesejahteraan umum atau sesuatu di lapangan kepentingan umum. Pada sisi lain, tujuan tersebut dapat terbatas, hanya untuk golongan tertentu tanpa menyebut nama per individu, melainkan hanya disebut menurut golongannya ataupun nama jenisnya,

1 Mulhadi, Hukum Perusahaan Bentuk-bentuk Badan Usaha di Indonesia, Bogor: Ghalia Indonesia, 2010, Hlm. 194.

2 Ibid., Hlm. 18.

${ }^{3}$ Gatot Supramono, Hukum Yayasan di Indonesia, Jakarta: Rineka Cipta, 2008, Hlm. 1. misalnya untuk kepentingan para tuna netra, para karyawan, pembangunan sekolah di suatu tempat tertentu ataupun untuk kepentingan anak-cucu keturunan dari pendirinya 4 .

Yayasan membutuhkan dana yang cukup untuk melakukan fungsinya sehingga yayasan dapat mencapai tujuannya. Jika yayasan tidak memiliki sumber penghasilan tetap, maka persoalan dana ini merupakan hal yang paling penting bagi yayasan. Berbedaa halnya jika yayasan itu sudah mempunyai banyak deposito di bank, sebab hanya dengan bunga deposito mereka bisa membiayai kegiatannya. Demikian pula jika ada donatur tetap bagi yayasan, maka dana tidak menjadi masalah bagi yayasan tersebut ${ }^{5}$.

Sebagai badan hukum, yayasan bisa melakukan perbuatan hukum sepanjang perbuatan hukum ituu tercakup dalam maksud serta tujuan yayasan yang dituangkan pada anggaran dasar yayasan. Jika yayasan melakukan perbuatan hukum ultra vires, yang di luar batas kecakapannya, maka perbuatan hukum tersebut adalah batal demi hukum ${ }^{6}$.

Yayasan sebagai lembaga sosial dengan bantuan yang tidak terlepas dari masalah keuangan dimana hal-hal ini dilakukan dalam bentuk bantuan sosial, pendidikan dan agama, dimana dana yang dikeluarkan berasal dari yayasann itu sendiri dimana organisasi yayasan memiliki kekayaan sendiri yang terpisah dari kekayaan pengurusnya maupun sumber dana yayasan yang berasal dari sumbangan pihak ketiga maupun dari usaha yang didirikan dari usaha yang didirikan oleh yayasan.

Adapun kekayaan yayasan yang terpisah berdasarkan Pasal 26 ayat (2) UU Yayasan bisa berupa uang, barang, maupun kekayaan lain didapat dari sumbangan atau

4 Anwar Borahima, Kedudukan Yayasan di Indonesia (Eksistensi, Tujuan dan Tanggung Jawab Yayasan), Jakarta: Prenada Media, 2010, Hlm. 88.

${ }^{5}$ Ibid., Hlm. 109.

${ }^{6}$ Mulhadi,Op.Cit., Hlm. 21. 
bantuan yang tidak mengikat, seperti wakaf, hibah, hibah wasiat dan perolehann lain yang tidak bertentangann dengan anggaran dasar yayasan dan/atau peraturann perundang-undangan yang berlaku.

Yayasan tergolong sebagai lembaga yang idealis dan kegiatannya termasuk mulia. Salah satu ruang lingkup kegiatannya di bidang keagamaan? ${ }^{7}$ Berdasarkan sejarah sosial budaya bisa dikatakann bahwa pesantren merupakan salah satu bentuk penyebaran agama Islam di negara Indonesia. Arti penting agama dan pendidikan telah berubah persepsinya semenjak adanya pesantren. Hal tersebut bisa dipahami bahwa dibutuhkannya pengkajian yang mendalam mengenai pengetahuan agama di dalam pesantren.

Sebagai suatu lembaga dan tempat pendidikan agama sekaligus sebagai tempat komunitas santri yang memahami ilmu agama Islam. Pesantren merupakan suatu lembaga yang mengandung makna keaslian Indonesia dan identik dengan makna keislaman tentunya. Keberadaan pesantren mulai dikenal di nusantara pada periode abad ke-13 sampai 17 M., sedangkan untuk di Pulau Jawa sekitar abad ke 15-16 M. ${ }^{8}$

Pesantren pertama kalinya di Jawa didirikan oleh Syekh Maulana Malik Ibrahim atau Syekh Maulana Maghribi 300400 tahun yang lalu. Hal tersebut membuktikan bahwa pesantren telah menjadi bagian dari budaya bangsa dalam bidang pendidikan dan ikut serta dalam mencerdaskan bangsa. ${ }^{9}$

Sejarah membuktikan besarnya konstribusi yang pernah dipersembahkan oleh lembaga yang satu ini, baik pada masa pra kolonial, kolonial serta pasca kolonial, bahkan di masa sekarang pun peran itu masih tetap dirasakan.

\footnotetext{
${ }^{7}$ Gatot Supramono, Op.Cit., Hlm. 113.

${ }^{8}$ Nurcholis Madjid, Bilik-bilik Pesantren: Sebuah Potret Perjalanan, Jakarta: Paramadina, 1997, Hlm. 3.

9 Wahjoetomo, Perguruan Tinggi Pesantren, Jakarta: Gema Insani Persada, 1997, Hlm. 70.
}

Pesantren bisa dikatakan memiliki peranserta mencerdaskan anak bangsa karena pesantren memiliki fungsi utama yaitu santri dapat mengkaji dan menguasai ilmu agama Islam secara lebih dalam. Oleh karena itu di dalam pesantren akan menghasilkan kader-kader ulama yang dapat melaksanakan kegiatan dakwah membawa misi penyebaran agama Islam yang bisa menjadi benteng pertahanan akhlak umat manusia yang hakiki. Berdasarkan hal tersebut maka seorang santri salah satunya bisa memahami materi yang diajarkan yang terdiri dari materi agama yang berbahasa Arab (kitab kuning). Berdasarkan hal tersebut bisa disebutkan bahwa lima elemen dasar yang menjadi tradisi pondok pesantren yaitu masjid, kiyai, santri, pondok, dan pengkajian kitab klasik (kitab kuning).

Kemajuan di segala bidang membuat kejadian yang sangat jauh yang notabene berbeda benua dapat diketahui saat ini juga, sementara jarak tempuh yang demikian sangat jauh dapat terjangkau dengan waktu yang singkat sehingga dunia seperti kampung yang begitu kecil. Keadaan hal tersebut disebut oleh Dohack Latief merupakan perkampungan global (global village). ${ }^{10}$

Perkembangan global disertai dengan proses perubahan politik, sosial dan budaya. Kemajuan teknologi komunikasi, transportasi dan informasi memberikan dampak yang berarti dalam kehidupan sehari-hari. Hal tersebut juga memberikan dampak bagi pesantren. Identitas pesantren dalam zaman modern ini perlu adanya notariat dalam hal pendiriannya. Pesantren perlu memiliki dasar hukum dalam hal pendirian pesantren.

Social Responsibility, Social mempunyai arti kehidupan di dalam masyarakat atau segala sesuatu yang berhubungan dengan kehidupan bermasyarakat; sedangkan, Responsibility memiliki makna yaitu tanggung jawab.

10 Dohack Latief, Ekonomi Global, Surabaya: Muhammadiyah University Press, 2000, HIm. 24. 
Tujuan Social Responsibility yaitu untuk mewujudkan pembangunan ekonomi berkelanjutan guna meningkatkan kualitas kehidupan dan lingkungan yang bermanfaat bagi diri sendiri, komunitas setempat, dan masyarakat pada umumnya. Selain itu tujuan Social Responsibility yaitu untuk tetap menciptakan hubungan yang serasi, seimbang, dan sesuai dengan lingkungan, nilai, norma, dan budaya masyarakat setempat.

Berdasarkan Undang-undang No. 23 Tahunn 2014 tentang Pemerintahan Daerah, khususnya Pasal 298 ayat (5) disebutkan ketentuan syarat penerima bansos, yakni yang pertama yaitu berbadan hukum untuk badan, lembaga, serta organisasi kemasyarakatan (ormas) tidak bisa hanya sampai notaris saja, tetapi juga wajib sampai ke Kementerian Hukum dan HAM (Kemenkumham). Oleh sebab itu jika pesantren menginginkan dana hibah dari pemerintah maka perlu menyesuaikan dengan undang-undang tersebut. Disamping hal tersebut lembaga keagamaan juga perlu terdaftar di Pemerintah Provinsi sekurang-kurangnya 3 (tiga) tahun. Tujuan pemerintah mengambil kebijakan seperti hal tersebut karena agar dana hibah bisa tepat sasaran, tepat penggunaan dan tepat manfaat sehingga dana hibah dapat dimanfatkan dengan sebaik-baiknya oleh pondok pesantren.

Untuk melakukan pemesanan nama yayasan pondok pesantren, proses pendirian dan pengesahan badan hukum dilakukan melalui Sistem Administrasi Badan Hukum (SABH) di situs yang telah disediakan oleh Direktorat Jenderal Administrasi Hukum Umum (Ditjen AHU).

Sebelum memulai pembuatan Akta Pendirian, Notaris harus lebih dahulu mengecek yayasan yang akan dipakai di dalam website "http://www.ahu.go.id", dimana hal tersebut melalui proses yang harus dilakukan dalam SABH yang disediakan oleh Ditjen AHU sebagai penyelenggara layanannya.
Notaris yang akan mengakses SABH haruslah mendaftarkan dirinya ke pihak penyelenggara layanan yang perwakilannya bertempat di Departemen Hukum dan Hak Asasi Manusia. Selanjutnya Notaris diberikan suatu kata kunci atau password yang terdiri dari rangkaian huruf atau angka yang bisa dirubah sesuai dengan keinginan Notaris yang bersangkutan. Selain itu Notaris juga dilengkapi dengan user ID atau nama dari pengguna, biasanya adalah nama dari Notaris itu sendiri, untuk digunakan dalam membuka atau memulai pengaksesan di dalam website SABH yang beralamat di http://www.ahu.go.id. Dengan demikian yang dapat melakukan permohonan pengesahan terhadap akta-akta Notaris hanyalah Notaris itu sendiri, dan tidak bisa lagi biro jasa atau orang lain dan bahkan orang dalam perusahaan turut mengurus langsung dalam proses pengesahan tersebut. Tetapi dalam hal pemesanan nama yayasan saat ini sudah bisa dilakukan secara online baik itu oleh masyarakat umum maupun oleh Notaris dengan syarat dan ketentuan yang ditetapkan oleh Ditjen AHU.

Setelah melihat uraian latar belakang penelitian tersebut diatas maka penulis dalam penelitian ini mengambil judul tentang: "TAX DEDUCTIBLE SEBAGAI KOMPENSASI KEGIATAN SOCIAL RESPONSIBILITY LEMBAGA NOTARIS DALAM PENGESAHAN BADAN HUKUM YAYASAN PONDOK PESANTREN".

Berdasarkan latar belakang penelitian di atas, maka penulis dapat mengidentifikasi masalah sebagai berikut:

1. Bagaimana social responsibility profesi notaris dalam menerapkan pelayanan publik dan profesional terhadap lembaga pendidikan dan keagamaan pondok pesantren?

2. Bagaimana pelaksanaan pajak penghasilan dari praktek social responsibility tersebut jika dihubungkan dengan kewajiban pembayaran pajak penghasilan dari setiap pembuatan akta notaris? 
3. Apa ada kebijakan-kebijakan tentang tax deductible terhadap praktek social responsibility notaris yang tidak memungut biaya akta atau honorarium dari klien yang mendirikan yayasan pondok pesantren secara online?

\section{METODE PENELITIAN}

Metode penelitian yang digunakan dalam penelitian ini adalah pendekatan yuridis normatif, yaitu hukum dikonsepsikan sebagai norma, kaidah, asas atau dogma-dogma/yurisprudensi. Tahap penelitian yuridis normatif, menggunakan studi kepustakaan (penelaahan terhadap literatur). Dalam penelitian ini bahan pustaka merupakan data dasar penelitian yang digolongkan sebagai data sekunder.

\section{PEMBAHASAN}

\section{A. SOCIAL RESPONSIBILITY PROFESI NOTARIS DALAM MENERAPKAN PELAYANAN PUBLIK DAN PROFESIONAL TERHADAP LEMBAGA PENDIDIKAN DAN KEAGAMAAN PONDOK PESANTREN}

Notaris dalam menjalankan profesinya memberikan pelayanan kepada masyarakat sepatutnya bersikap sesuai aturan yangg berlaku. Ini penting karena Notaris melaksanakan tugas jabatannya tidaklah semata-mata untuk kepentingan pribadi, melainkan juga untuk kepentingan masyarakat, serta mempunyai kewajiban untuk menjamin kebenaran dari akta-akta yang dibuatnya, karena itu seorang Notaris dituntut untuk lebih peka, jujur, adil serta transparan dalam pembuatan suatu akta agar menjamin semua pihak yang terkait langsung dalam pembuatan sebuah akta otentik. Dalam melaksanakan tugas jabatannya seorang Notaris harus berpegang teguh kepada Kode Etik Jabatan Notaris, karena tanpa itu, harkat dan martabat profesionalisme akan hilang dan tidak lagi mendapat kepercayaan dari masyarakat.
Notaris juga dituntut untuk memiliki nilai moral yang tinggi, karena dengan adanya moral yangg tinggi maka Notaris tidak akan menyalahgunakan wewenang yang ada padanya, sehingga Notaris akan dapat menjaga martabatnya sebagai seorang pejabat umum yang memberikan pelayanan yang sesuai dengan aturan yang berlaku dan tidak merusak citra Notaris itu sendiri. Sebagaimana harapan Komar Andasasmita, agar setiap Notaris mempunyai pengetahuan yang cukup luas dan mendalam serta keterampilan sehingga merupakan andalan masyarakat dalam merancang, menyusun dan membuat berbagai akta otentik, sehingga susunan bahasa, teknis yuridisnya rapi, baik dan benar, karena disamping keahlian tersebut diperlukan pula kejujuran atau ketulusan dan sifat atau pandangan yang objektif. ${ }^{11}$

Perlindungan hukum terhadap Notaris dalam menjalankan tugas dan wewenangnya demi terlaksananya fungsi pelayanan dan tercapainya kepastian hukum dalam memberikann pelayanan kepada masyarakat, telah diatur dan dituangkan dalam undang-undang tersendiri, yaitu Undang-undang No. 2 Tahun 2014 tentang Jabatan Notaris, Lembaran Negara Republik Indonesia Tahun 2014 No. 3. Pasal 1 angka 1 Undangundang No. 2 Tahun 2014 tentang Jabatan Notaris. Notaris dikatakan sebagai pejabat umum karena Notaris diangkat dan diberhentikan oleh pemerintah. Meskipun Notaris diangkat serta diberhentikan oleh pemerintah, akan tetapi Notaris tidak bisa disamakan dengan pegawai negeri yang juga diangkat serta diberhentikan oleh pemerintah. Dan yang membedakannya ialah Notaris merupakan pegawai pemerintah tanpa menerima gaji dari pemerintah.

Diberlakukannya Undang-undang No. 2 Tahun 2014 tentang Jabatan Notaris diharapkan bahwa akta autentik yang

\footnotetext{
11Komar Andasasmita, Notaris Dengan Sejarah, Peranan, Tugas Kewajiban, Rahasia Jabatannya, Bandung: Sumur, 1981, Hlm. 14.
} 
dibuat oleh atau di hadapan Notaris mampu menjamin kepastian, ketertiban, dan perlindungan hukum. Undang-undang No. 2 Tahun 2014 tentang Jabatan Notaris sudah menetapkan dalam Pasal 15 ayat (1) tentang kewenangan seorang Notaris yaitu Notaris berwenang membuat akta autentik mengenai semua perbuatan, perjanjian, dan penetapan yang diharuskan oleh peraturan perundang-undangan dan/atau yang dikehendaki oleh yang berkepentingan untuk dinyatakan dalam akta autentik, menjamin kepastian tanggal pembuatan akta, menyimpan akta, memberikan grosse, salinan dan kutipan akta, semuanya itu sepanjang pembuatan akta itu tidak juga ditugaskann atau dikecualikan kepada pejabat lain atau orang lain yang ditetapkann oleh undang-undang. Selain itu dalam Pasal 15 ayat (2) Undang-undang No. 2 Tahun 2014 tentang Jabatan Notaris menyatakan Notaris juga berwenang mengesahkan tanda tangan dan menetapkan kepastian tanggal surat di bawah tangan dengan mendaftar dalam buku khusus, membukukan surat di bawah tangan dengan mendaftar dalam buku khusus, membuat kopi dari asli surat di bawah tangan berupa salinan yang memuat uraian sebagaimana ditulis dan digambarkan dalam surat yang bersangkutan, melakukan pengesahan kecocokan fotokopi dengan surat aslinya, memberikan penyuluhan hukum sehubungan dengan pembuatan akta, membuat akta yangg berkaitan dengan pertanahan dan membuat akta risalah lelang. Dari beberapa kewenangan tersebut jasa seorang Notaris kebanyakan dibutuhkan oleh masyarakat dalam hal pembuatan akta autentik.

Berdasarkan pasal tersebut Notaris mempunyai wewenang untuk membuat akta autentik. Terdapat dua golongan akta autentik yang dibuat oleh Notaris yaitu akta autentik yang dibuat oleh Notaris dimana merupakan suatu akta yang dibuat oleh Notaris mengenai suatu tindakan yang dilakukan atas suatu keadaan yang disaksikan oleh Notaris dan juga akta autentik yang dibuat di hadapan Notaris ialah akta yang dibuat dihadapan Notaris yang memuat uraian tentang hal-hal yang diterangkan oleh pihak yang menghadap kepada Notaris. Dengan adanya Undangundang No. 2 Tahun 2014 tentang Jabatan Notaris kewenangan Notaris dalam membuat akta autentik nanti dalam penerapannyan akta tersebut mampu menjamin kepastian, ketertiban, dan perlindungan hukum bagi semua pihak yang terkait. Akta autentik merupakan alat bukti tulisan atau surat yang bersifat sempurna. Akta autentik memiliki 3 (tiga) kekuatann pembuktian yaitu kekuatan pembuktian lahiriah (uitwendige bewijskracht) yang merupakan kemampuan akta itu sendiri untuk membuktikan keabsahanya sebagai akta autentik. Kekuatan pembuktian formill (formele bewijskracht) yang memberikan kepastian bahwa sesuatu kejadian dan fakta tersebut dalam akta betul-betul diketahui dan juga didengar oleh Notaris serta diterangkan oleh para pihak yang menghadap. Kekuatan pembuktian materiil (materiele bewijskracht) yang merupakan kepastian tentang materi atau isi suatu akta.

Notaris sebagai pejabat umum (openbaar ambtenaar) berwenang membuat akta autentik, sehubungan dengan kewenangannya tersebut Notaris dapat dibebani tanggungg jawab atas perbuatannya dalam membuat akta autentik yang tidak sesuai dengan ketentuan yang berlaku atau dilakukan secara melawan hukum. Pertanggungjawaban merupakan suatu sikap atau tindakan untuk menanggung segala akibat dari perbuatan yang dilakukan atau sikap untuk menanggung segala resiko ataupun kosekuensinya yang ditimbulkan dari suatu perbuatan.

Jadi, tanggung jawab secara sosial tidak hanya terbatas pada konsep pemberian dana saja, tetapi konsepnyaa sangat luas dann tidak bersifat statis dan pasif juga statis, hanya dikeluarkan dari perusahaan akan tetapi hak dan kewajibann yang 
dimiliki bersama antara stakeholders. Konsep Social Responsibility melibatkan tanggung jawab kemitraan antara pemerintah, lembaga, sumberdaya komunitas, juga komunitas lokal (setempat). Kemitraan ini tidaklah bersifat pasif atau statis. Kemitaraan ini merupakan tanggung jawab bersama secara sosial antara stakeholders.

Suatu hal yang tidak terlepas dalam wacana sosial intelektual di Indonesia ialah Pondok Pesantren. Ia merupakan model sistem sosial sekaligus sebagai sistem intelektual yang pertama dan tertua di Indonesia. Keberadaannya mengilhami model dan sistem-sistem pendidikan yang ditemukan saat ini. Ia bahkan tidak lapuk dimakan zaman dengan segala perubahannya. Karenanya banyak pakar, baik lokal maupun internasional melirik Pondok Pesantren sebagai bahan kajian, makaa tidak jarang beberapa tesis dan disertasi membahas tentang lembaga pendidikan Islam tertua ini sebagai obyek maupun subyek penelitiannya.

Di antara sisi yang menarik para pakar dalam mengkaji lembaga ini adalah karena "modelnya". Sifat ke-Islaman dan juga keIndonesiaan yang terintegrasi dalam pesantren menjadi daya tariknya. Belum lagi kesederhanaan, sistem yang terkesan apa adanya, hubungann Kyai dan santri serta keadaan fisik yang serba sederhana. Walau di tengah suasana yang demikian, yang menjadi magnet terbesar ialah peran dan kiprahnya bagi masyarakat, negara dan juga umat manusia yang tidak bisa dianggap sebelah mata. Sejarah membuktikan besarnya konstribusi yang pernah dipersembahkan lembaga yang satu ini, baik di masa pra kolonial, kolonial dan pasca kolonial, bahkan di masa kini pun peran itu masih tetap dirasakan.

Melihat betapa pentingnya pondok pesantren, maka pada bagian ini penulis akan memberikan gambaran tentang pondok pesantren tersebut. Pengertian pesantren berasal dari kata santri yang bermakna seseorang yang belajar agama Islam, kata santri tersebut kemudian mendapat awalan "pe" dan akhiran "an" yang artinya tempat tinggal santri. Dengan demikian pesantren mempunyai arti tempat orang berkumpul untuk belajar agama Islam. ${ }^{12}$ Ada juga yang mengartikan pesantren adalah suatu lembaga pendidikan Islam Indonesia yang bersifat "tradisional" untuk mendalami ilmu tentang agama Islam dan juga mengamalkan sebagai pedoman hidup keseharian.

Sedangkan secara istilah pesantren merupakan lembaga pendidikan Islam dimana para santri biasa tinggal di pondok (asrama) dengan materi pengajaran kitabkitab klasik dan juga kitab-kitab umum bertujuan untuk menguasai ilmu agama Islam secara detail serta mengamalkan sebagai pedoman hidup keseharian dengan menekankan penting moral dalam kehidupan bermasyarakat.

Pondok pesantren secara definisi tidak dapat diberikan batasan yang tegas melainkan terkandung fleksibilitas pengertian yang memenuhi ciri-ciri yang memberikan pengertian pondok pesantren. Jadi pondok pesantren belum ada pengertian yang lebih konkrit karena masih meliputi beberapa unsur untuk bisa mengartikan pondok pesantren secara komprehensif.

Dengan demikian, sesuai dengan arus dinamika zaman, definisi serta persepsi terhadap pesantren menjadi berubah pula. Kalau pada tahap awal pesantren diberi makna dann pengertian sebagai lembaga pendidikan tradisional tetapi saat sekarang pesantren sebagai lembaga pendidikan tradisional tak lagi selamanya benar.

\section{B. PELAKSANAAN PAJAK PENGHASILAN DARI PRAKTEK SOCIAL RESPONSIBILITY DIHUBUNGKAN DENGAN KEWAJIBAN PEMBAYARAN PAJAK PENGHASILAN DARI SETIAP PEMBUATAN AKTA NOTARIS}

\footnotetext{
${ }^{12}$ Asrohah, Pelembagaan Pesantren Asal-usul dan Perkembangn Pesantren di Jawa, Hlm. 30.
} 


\section{Honorarium Notaris}

Gaji, upah, tunjangan, honorarium, komisi, bonus, gratifikasi, uang pensiun, atau imbalan dalam bentuk lainnya termasuk penerimaan berupa pembayaran berkala, seperti alimentasi atau tunjangan seumur hidup yang dibayar secara berulang-ulang dalam waktu tertentu merupakan objek Pajak Penghasilan (PPh) Pasal 21.

Penghasilan yang terhutang $\mathrm{PPh}$ Pasal 21 dapat dikenakan pada penghasilan yang diterima oleh pegawai tetap, pegawai tidak tetap, penerima pensiun, dan bukan pegawai. Notaris adalah termasuk bukan pegawai yang merupakan tenaga ahli.

Dalam Pasal 1 angka 1 jo. Pasal 15 ayat (1) Undang-undang No.2 Tahun 2014 tentang Jabatan Notaris, ditentukan bahwa yang dimaksud dengan Notaris adalah pejabat umum yang berwenang untuk membuat akta autentik, mengenai semua perbuatan, perjanjian, dan juga ketetapan yang diharuskan oleh peraturan perundang-undangan dan/atau yang dikehendaki oleh yang berkepentingan, untuk dinyatakan dalam akta autentik, menjamin kepastian tanggal pembuatan akta, menyimpan akta, memberikan grosse, salinan dan kutipan akta, semuanya itu sepanjang pembuatan akta-akta itu tidak juga ditugaskan atauu dikecualikan kepada pejabat lain atau orang lain yang ditetapkan oleh undang-undang.

Walaupun menurut definisi di atas ditegaskan bahwa seorang notaris adalah pejabat umum (openbare ambtenaar), namun notaris bukanlah pegawai menurut undang-undang kepegawaian negeri. Notaris tidak menerima gaji, bukan bezoldigd staatsmabt, tetapi menerima honorarium dari kliennya berdasarkan peraturan perundang-undangan. ${ }^{13}$

Dalam menjalankan tugasnya, Notaris tunduk serta terikat dengan aturan-aturan

\footnotetext{
${ }^{13}$ Komar Andasasmita, Notaris I : Peraturan Jabatan, Kode Etik dan Asosiasi Notaris/Notariat, Ikatan Notaris Indonesia Daerah Jawa Barat, Bandung, 1991, Hlm. 94.
}

yang ada yakni Undang-undang No. 2 Tahun 2014 tentang Jabatan Notaris, Kode Etik Notaris dan peraturan hukum lainnya pada umumnya. Menurut hukum yang merupakan produk atau hasil pekerjaan Notaris adalah berupa akta yang dibuat oleh Notaris.

Selain itu Notaris juga berhak menerima honorarium atas jasa hukum yang diberikan sesuai dengan kewenangannya dimana besarnya honorarium yang diterima oleh Notaris didasarkan pada nilai ekonomis dan nilai sosiologis dari setiap akta yang dibuatnya.

Dalam ketentuan Pasal 36 ayat (3) Undang-undang No. 2 Tahun 2014 tentang Jabatan Notaris disebutkan bahwa nilai ekonomis ditentukan dari objek setiap akta sebagai berikut:

1. Sampai dengan Rp100.000.000,00 (seratus juta rupiah) atau ekuivalen gram emas ketika itu, honorarium yang diterima paling besar ialah 2,5\% (dua koma lima persen);

2. Di atas $\mathrm{Rp} 100.000 .000,00$ (seratus juta rupiah) sampai dengan $\mathrm{Rp}$ 1.000.000.000,00 (satu miliar rupiah) honorarium yang diterima paling besar 1,5 $\%$ (satu koma lima persen); atau

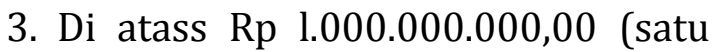
miliar rupiah) honorarium yang diterima didasarkan pada kesepakatan antara Notaris dengan para pihak, tetapi tidak melebihi 1\% (satu persen) dari objek yang dibuatkan aktanya. Nilai sosiologis ditentukan berdasarkan fungsi sosial dari objek setiap akta dengan honorarium yang diterima paling besar Rp 5.000.000,00 (lima juta rupiah).

Notaris wajib memberikan jasa hukum di bidang kenotariatan secara cuma-cuma kepada orang. Akta yang mempunyai fungsi sosial, misalnya, akta pendirian yayasan, akta pendirian sekolah, akta tanah wakaf, akta pendirian rumah ibadah, atau akta pendirian rumah sakit. Maka Honorarium itulah yang dipotong oleh pemotong pajak. 


\section{Pemotong PPh Pasal 21}

Dalam sistem perpajakan dikenal beberapa sistem pengenaan pajak, yakni Official Assessment System, Self Assesment System, dan With Holding System. Official Assessment System merupakan suatu sistem pengenaan pajak yang memberi wewenang kepada pemerintah (fiskus) untuk menentukan besarnya pajak yang terutang oleh wajib pajak. Salah satu contoh pajak yang masih menggunakan sistem ini adalah Pajak Bumi dan Bangunan.

Self Assesment System merupakan suatu sistem pengenaan pajak yang memberi wewenang kepada wajib pajak untuk menentukan sendiri besarnya pajak yang terutang. Sistem self assesment ini umumnya diterapkan pada jenis pajak yang memandang wajib pajaknya cukup mampu untuk diserahkan tanggung jawab menghitung dan menetapkan utang pajaknya sendiri. Sebagai contoh misalnya dalam Pajak Penghasilan (PPh) Pajak Pertambahan Nilai Atas Barang dan Jasa (PPN) dan juga Pajak Penjualan Atas Barang Mewah (PPnBM).

Berdasarkan uraian diatas dapat dikatakan yang melakukan pemotongan $\mathrm{PPh}$ Pasal 21 terhadap honorarium yang diterima oleh Notaris adalah badan termasuk bentuk usaha tetap yaitu PT, CV, BUMN, BUMD, Fa, Kongsi, Koperasi, Dana Pensiun, Persekutuan, Perkumpulan, Yayasan, Ormas, Orsopol, Lembaga, Bank, dan Badan lainnya.

Kewajiban Pemotong PPh Pasal 21 ialah menghitung, memotong, menyetorkan dan melaporkan $\mathrm{PPh}$ Pasal 21 yang terutang untuk setiap bulan kalender, sebagaimana dimaksud dalam Pasal 22 ayat (4) Peraturan Menteri Kuangan No.252/PMK.03/2008. Pemotong pajak juga diwajibkan utuk mendaftarkan diri terlebih dahulu ke Kantor Pelayanan Pajak sesuai dengan ketentuan yang berlaku, diatur pada Pasal 22 ayat (1) Peraturan Menteri Kuangan No.252/PMK.03/2008.
3. Pemotongan PPh Pasal 21 atas Honorarium Notaris

Undang-undang No. 36 Tahun 2008 tentang Pajak Penghasilan telah menegaskan bahwa setiap pemotong pajak wajib memotong $\mathrm{PPh}$ Pasal 21 atas honorarium yang dibayarkannya kepada Notaris, namun dalam pelaksanaannya di Kabupaten Bogor, tidak semua badan sebagai pemotong pajak melakukan pemotongan PPh Pasal 21.

Berdasarkan hasil penelitian dengan tujuh responden Notaris di Kabupaten Bogor, 5 (lima) orang responden atau sebesar 71,43\% menyatakan semua badan (PT, CV, BUMN, BUMD, Fa, Kongsi, Koperasi, Dana Pensiun, Persekutuan, Perkumpulan, Yayasan, Ormas, Orsospol, Lembaga, Bank, dan Badan lainnya) yang membayarkan fee atau honorarium atau imbalan sehubungan dengan jasa yang sudah di berikan Notaris melakukan pemotongan PPh Pasal 21 dari jumlah yang dibayarkannya. Sedangkan 2 (dua) orang responden atau sebanyak 28,57\% menyatakan tidak semua badan yang membayarkan fee atau honorarium ataupun imbalan sehubungan dengan jasa yang sudah di berikan Notaris, melakukan pemotongan PPh Pasal 21 dari jumlah yang dibayarkannya.

Badan yang melakukan pemotongan $\mathrm{PPh}$ Pasal 21 atas honorarium yang diberikan kepada Notaris diiKabupaten Bogor hanya berkisar antara 50\% sampai dengan $75 \%$. Dengan demikian persentase Wajib Pajak Badan yang melakukan pemotongan PPh Pasal 21 atas honorarium yang dibayarkannya kepada Notaris di Kabupaten Bogor, hanya sampai dengan 75\%, padahal di tahun 2015, KPP Pratama Kabupaten Bogor pernah melakukan penyuluhan mengenai $\mathrm{PPh}$ Pasal 21 sebanyak 4 (empat) kali, dengan materi penyuluhan mengenai kewajiban pemotong PPh Pasal 21, hak-hak pemotong 
PPh Pasal 21, dan SPT Masa PPh Pasal 21.14 KPP Pratama Kabupaten Bogor juga pernah melaksanakan penyuluhan mengenai $\mathrm{PPh}$ Pasal 21. Pada tahun 2015 telah dilaksanakan sebanyak 6 (enam) kali. Dengan materi penyuluhan mengenai kewajiban pemotong PPh Pasal 21, hak-hak pemotong PPh Pasal 21, dan SPT Masa PPh Pasal 21.15

Dengan telah dilaksanakannya penyuluhan mengenai $\mathrm{PPh}$ Pasal 21, seharusnya badan sebagai pemotong pajak sudah mengetahui kewajibannya sebagai pemotong pajak dan melakukan pemotongan PPh Pasal 21 atas honorarium yang dibayarkannya kepada Notaris di Kabupaten Bogor.

4. Penghitungan $\mathrm{PPh}$ Pasal 21 atas Honorarium Notaris

Untuk dapat melakukan pemotongan dengan benar tentu saja pemotong pajak harus melakukan penghitungan PPh Pasal 21 yang terutang. Dalam menghitung $\mathrm{PPh}$ Pasal 21 yang terutang harus lebih dulu diketahui dan dipahami penerima penghasilan yang dipotong PPh Pasal 21, penghasilan yang dipotong PPh Pasal 21, dasar pengenaan $\mathrm{PPh}$ Pasal 21 dan tarif pemotongan PPh Pasal 21.

Berdasarkan ketentuan PPh Pasal 21, penerima penghasilan yang dipotong $\mathrm{PPh}$ Pasal 21 adalah:

a. Pegawai tetap.

b. Tenaga lepas (seniman, olahragawan, penceramah, pemberii jasa, pengelolaa proyek, peserta perlombaan, petugas dinas luar asuransi), distributor MLM/direct selling dan kegiatan sejenis. Penerima pensiun, mantan pegawai, termasuk orang pribadi atau ahli warisnya yang menerima Tabungan Hari Tua atau Jaminan Hari Tua.

\section{c. Penerima honorarium. \\ d. Penerima upah.}

\footnotetext{
${ }^{14}$ Wawancara dengan Kepala Seksi Pengawasan dan Konsultasi IV atas nama Kepala KPP Pratama Kabupaten Bogor pada tanggal 13 April 2017.

${ }^{15}$ Wawancara dengan Account Representative KPP Pratama Kabupaten Bogor pada tanggal 13 April 2017.
}

\section{e. Tenaga ahli.}

Menurut ketentuan tersebut diatas, yang dimaksud dengan tenaga ahli antara lain Pengacara, Akuntan, Arsitek, Dokter, Konsultan, Notaris, PPAT, Penilai, serta Aktuaris.

Dalam Pasal 5 ayat (1) Peraturan Menteri Keuangan No. 252/PMK.03/2008 tentang Petunjuk Pelaksanaan Pemotongan Pajak Atas Penghasilan Sehubungan Dengan Pekerjaan, Jasa dan Kegiatan Orang Pribadi ditentukan bahwa penghasilan yang dipotong PPh Pasal 21 adalah:

1. Penghasilan yang diterima ataupun diperoleh pegawai tetap, baik berupa penghasilan yang bersifat teratur maupun tidak teratur;

2. Penghasilan yang diterima atau diperoleh penerima pensiun secara teratur berupa uang pensiun atau penghasilan sejenisnya;

3. Penghasilan sehubungan dengan pemutusan hubungan kerja dan penghasilan sehubungan dengan pensiun yang diterima secara sekaligus berupa uang pesangon, uang manfaat pensiun, tunjangan hari tua atau jaminan hari tua, dan pembayaran lain sejenis;

4. Penghasilan pegawai tidak tetap atau tenaga kerjaa lepas, berupa upah harian, upah mingguan, upa satuan, upah borongan atau upah yang dibayarkan secara bulanan;

5. Imbalan kepada bukan pegawai, antara lain berupa honorarium, komisi, fee, dan imbalan sejenis dengan nama dan dalam bentuk apapun sebagai imbalan sehubungan dengan pekerjaan, jasa, dan kegiatan yang dilakukan;

6. Imbalan kepada pesertaa kegiatan, antara lain berupa uang saku, uang representasi, uang rapat, honorarium, hadiah atau penghargaan dengan nama dan dalam bentuk apapun, dan imbalan sejenis dengan nama apapun.

Penghasilan yang dipotong PPh Pasal 21 sebagaimana dimaksud pada Pasal 5 
ayat (1) di atas, termasuk pula penerimaan dalam bentuk natural dan/atau kenikmatan lainnya dengan nama dan dalam bentuk apapun. Berdasarkan uraian diatas penghasilan yang dipotong PPh Pasal 21 bagi Notaris adalah berupa honorarium atas jasa yang telah dilakukannya.

Dasar pengenaan dan pemotongan $\mathrm{PPh}$ Pasal 21 bagi Notaris adalah 50\% (lima puluh persen) dari jumlah penghasilan bruto yang diterimanya. Hal ini sebagaimana diatur dalam Pasal 9 ayat (1) huruf c Per-31/PJ/2009. Tarif pemotongan atas $\mathrm{PPh}$ Pasal 21 adalah tarif pajak sebagaimana dimaksud dalam Pasal 17 ayat (1) huruf a. Dengan demikian dasar pengenaan dan besarnya tarif pajak $\mathrm{PPh}$ Pasal 21 yang dipotong dari penghasilan Notaris adalah tarif pasal 17 ayat (1) huruf a UU PPh x (50\% x penghasilan bruto). Dalam prakteknya di Kabupaten Bogor, tarif pajak dan dasar pengenaan PPh Pasal 21 atas honorarium Notaris.

Dari hasil penelitian dapat dilihat bahwa dalam hal besarnya tarif pajak dan dasar pengenaan pajak $\mathrm{PPh}$ Pasal 21 umumnya Notaris mengetahui pengenaan tarif PPh Pasal 21 ini sesuai dengan Pasal 17 ayat (1) huruf a Undang-undang Nomor 36 tahun 2008 tentang Pajak Penghasilan (PPh).

Besarnya PPh Pasal 21 atas penghasilan yang dibayarkan kepada tenaga ahli yang melakukan pekerjaan bebas dihitung dengan cara menerapkan tarif Pasal 17 atas jumlah kumulatif jumlah kumulatif $50 \%$ (lima puluh persen) dari jumlah penghasilann bruto yang dibayarkan atau terutang dalam 1 (satu) tahun kalender.

Jika dibandingkan dengan ketentuan sebelum tahun 2009, dimana besarnya tarif efektif PPh Pasa1 21 atas penghasilan yang dibayarkan kepada tenaga ahli adalah sebesar 7,5\% dari Penghasilan Bruto, terlihat bahwa perhitungan PPh Pasal 21 atas imbalan tenaga ahli sebelum tahun 2009 jauh lebih sederhana dibandingkan dengan yang saat ini berlaku.
Dalam menghitung besarnya PPh Pasal 21 yang terutang dan harus dipotong, pihak pemberi penghasilan selakuu pemotong pajak tidak perlu menghitung berapaa jumlah kumulatif penghasilan yang telah dibayarkan kepada tenaga ahli yang bersangkutan dalam satu tahun kalender. Perhitungan kumulatif hanya diperlukan pada saat pemotong pajak melaporkan SPT Tahunan PPh Pasal 21.

Mulai tahun 2009, pada saat menghitung PPh 21 yang terutang, untuk dapat menerapkan tarif yang benar, pemotong pajak harus mengetahuii jumlah kumulatif penghasilan yang telah dibayarkan kepada tenaga ahli tersebut sampai dengan saat pemotongan.

5. Pemberian Bukti Pemotongan PPh Pasal 21 atas Honorarium Notaris

Setelah memotong PPh Pasal 21 atas honorarium yang diberikan kepada Notaris, pemotong pajak harus memberikan bukti pemotongan $\mathrm{PPh}$ Pasal 21 untuk setiap melakukan pemotongan PPh Pasal 21. Namun dalam prakteknya masih terdapat badan sebagai pemotong pajak yang tidak memberikan bukti pemotongan PPh Pasal 21 atas honorarium yang diberikan kepada Notaris.

Dari hasil penelitian diketahui bahwa 5 (lima) responden atau sebanyak 71,43\% menyatakan semua badan yang memotong PPh Pasal 21 atas honorarium yang telah dibayarkan kepada mereka memberikan bukti pemotongan PPh Pasal 21. Sedangkan 2 (dua) responden atau sebanyak 28,57\% menyatakan tidak semua badan yang memotong PPh Pasal 21 atas honorarium yang mereka terima memberikan bukti pemotongan PPh Pasal 21.

Berdasarkan jumlah persentase sebesar 28,57\%, pemberian bukti pemotongan PPh Pasal 21 oleh badan yang membayarkan honorarium kepada Notaris di Kabupaten Bogor persentasenya berkisar antara 50\% sampai dengann 75\%.

Dalam hal pemberian bukti pemotongan pajak PPh Pasal 21 atas jasa yang diberikan Notaris, menurut 2 (dua) 
orang responden atau $100 \%$ menyatakan badan yang memberikan bukti pemotongan PPh Pasal 21 adalah sebesar lebih 50\% sampai $75 \%$. Jadi badan yang memberikan bukti pemotongan PPh Pasal 21 terhadap honorarium yang dibayarkan kepada Notaris, persentasenya adalah sampai dengan $75 \%$.

Setelah dilakukan pemotongan $\mathrm{PPh}$ Pasal 21 olehh pemotong pajak, maka pemotong pajak wajib memberikan bukti pemotongan PPh Pasal 21 tersebut karena hal ini merupakan hak dari wajib pajak. Dari hasill penelitian sebanyak 7 (tujuh) responden atau 100\% mendapatkan bukti pemotongan $\mathrm{PPh}$ Pasal 21 setiap kali mereka melakukan pemotongan $\mathrm{PPh}$ Pasal 21.

Berdasarkan Peraturan Dirjen Pajak, No. Per-31/PJ/2009 Pasal 23 ayat (3) bukti pemotongan $\mathrm{PPh}$ Pasal 21 diberikan pada saat melakukan pemotongan PPh Pasal 21. Apabila Honorarium yang diterima Notaris telah dipotong PPh Pasal 21, namun mereka tidak mendapat bukti pemotongan tersebut, maka mereka tidak bisa mengkreditkan PPh Pasal 21 tersebut dalam pajak penghasilan terutang pada akhir tahun pajak bersangkutan.

\section{KEBIJAKAN-KEBIJAKAN TENTANG TAX DEDUCTIBLE TERHADAP PRAKTEK SOCIAL RESPONSIBILITYNOTARIS YANG TIDAK MEMUNGUTT BIAYA AKTA ATAU HONORARIUM DARI KLIEN YANG MENDIRIKAN YAYASAN PONDOK PESANTREN SECARA ONLINE}

\section{Tax Deductible dan CSR}

Tax Deductible adalah biaya yang diakui oleh pajak, biasanya ditujukan kepada beban/biaya yang menurut ketentuan menjadi pengurang penghasilan Bruto sebagaimana diatur dalam Pasal 6 UU PPh.

Belakangan ini, aktivitas CSR sudah berkembang menjadi bagian dari strategi bisnis perusahaan, utamanya terkait dengan fungsi pemasaran. Untuk dapat menghasilkan program CSR yang bisa menghasilkan program business value sekaligus tax favorable, ada baiknya jika wajib pajak mempertimbangkan aspek perpajakan saat merancang program CSRnya.

Dalam batasan tertentu, ketentuan perpajakan Indonesia juga memberikan skema insentif untuk program-program CSR. Pemberian insentif ini diusung sebagai bentuk akomodasi pemerintah atas kepentigan publik dalam jangka panjang. Disini, skema insentif tax exemtion, tax deduction, atau tax credit yang digunakan disesuaikan dengan dasar hukum yang berlaku di Indonesia serta aplikasi program-program CSR yang terjadi dalam masyarakat.

Dalam ranah Pajak Penghasilan (PPh), ketentuan terkait aktivitas CSR diatur dalam Pasal 4 UU PPh. Seperti yang dijelaskan dalam ayat (1) huruf d angka 4 pasal tersebut, Objek $\mathrm{PPh}$ adalah penghasilan, termasuk di dalamnya keuntungan karena penjualan atau karena pengalihan harta berupa hibah, bantuan, atau sumbangan, kecuali yang diberikan kepada keluarga sedarah dalam garis keturunan lurus satu derajat dan badan keagamaan, badan pendidikan, badan sosial termasuk yayasan, koperasi, atau orang pribadi yang menjalankan usaha mikro dan kecil, yang ketentuannya diatur lebih lanjut dengan Peraturan Menteri Keuangan (PMK), sepanjang tidak ada hubungan dengan usaha, pekerjaan, kepemilikan, atau penguasaan di antara pihak-pihak yang bersangkutan. Itu artinya, keuntungan karena penjualan atau karena pengalihan harta berupa hibah, bantuan, atau sumbangan yang diberikan kepada keluarga sedarahh dalam garis keturunan lurus satu derajat dan badan keagamaan, badan pendidikan, badan sosial termasuk yayasan, koperasi, atauu orang pribadi yang menjalankan usaha mikro dan kecil, bukan merupakan objek $\mathrm{PPh}$ bagi yang menerima.

Kemudian, dalam Pasal 4 ayat (3) huruf a UU PPh juga diatur aktivitas CSR lain yang 
dikecualikan dari objek PPh. Bantuan atau sumbangan, termasuk zakat yang diterima oleh badan amil zakat atau lembaga amil zakat yang dibentuk atau disahkan oleh pemerintah dan yang diterima oleh penerima zakat yang berhak atau sumbangan keagamaan yang sifatnya wajib bagi pemeluk agama yang dibentuk atau disahkan oleh pemerintah dan yang diterima oleh penerima dengan atau berdasarkan peraturan pemerintah dan harta hibahan yang diterima oleh keluarga sedarah dalam garis keturunan lurus satu derajat, badan keagamaan, badan pendidikan, badan sosial termasuk yayasan, koperasi, atau orang pribadi yang menjalankan usaha mikro dan kecil, yang ketentuannya diatur dengan atau berdasarkan PMK, sepanjang tidak ada hubungan dengan usaha, pekerjaan, kepemilikan, atau penguasaan di antara pihak-pihak yangg bersangkutan.

Selain itu, dalam Pasal 4 ayat (3) huruf $\mathrm{k}$ UU PPh, diatur bahwa penghasilan yang diterima atauu diperoleh perusahaan modal ventura berupa bagian laba dari badan pasangan usaha yang didirikan dan menjalankan usaha atau kegiatan di Indonesia, dikecualikan dari Objek PPh. Dengan catatan, badan pasangan usaha tersebut merupakan perusahaan mikro, kecil, menengah, atau yang menjalankan kegiatan dalam sektor-sektor usaha yang diatur dengan atau berdasarkan PMK dan sahamnya tidak diperdagangkan di bursa efek di Indonesia.

Tidak berhenti sampai disitu, dalam Pasal 4 ayat (3) huruf l, m, dan UU PPh juga diatur pengecualian pengenaan $\mathrm{PPh}$ atas aktivitas CSR. Seperti halnya beasiswa yang memenuhi persyaratan tertentu, sisa lebih diterima atau diperoleh badan atau lembaga nirlaba yang bergerak dalam bidang pendidikan dan atau bidang penelitian dan pengembangan yang sudah terdaftar pada instansi yang membidanginya yang ditanamkan kembali dalam bentuk sarana dan prasarana kegiatan pendidikan dan atau penelitian dan pengembangan dalam jangka waktu paling lama 4 (empat) tahun sejak diperolehnya sisa lebih tersebut, serta bantuan atau santunan yang dibayarkan oleh Badan Penyelenggara Jaminan Sosial kepada Wajib Pajak tertentu.

Ketentuan yang telah diuraikan di atas merupakan bentuk dari kebijakan pajakyang berupa tax exemption untuk aktivitas CSR dalam ranah PPh. Disisi lain, dalam ranah Pajak Pertambahan Nilai (PPN) juga diatur mengenai tax exemption terkait aktivitass CSR. Sebagaimana dijelaskan dalam Pasal 4A ayat (3) UU Nomor 42 Tahun 2009 (UU PPN) bahwa jasa pelayanan kesehatan medis, jasa pelayanan sosial, jasa keagamaan, jasa pendidikan, dan jasa kesenian dan juga hiburan tidak dikenakan PPN.

\section{Social Responsibility Notaris}

Notaris merupakan salah satu profesi dibidang hukum. Profesi notaris lahir dari hasil interaksi antara sesama anggota masyarakat dan dikembangkan dan diciptakan oleh masyarakat sendiri. ${ }^{16}$ Notaris menurut Undang-undang No. 2 Tahun 2014 tentang Perubahan Atas Undang-undang No. 30 Tahun 2004 tentang Jabatan Notaris selanjutnya Notaris adalah pejabat umum yang berwenang untuk membuat akta autentik dan memiliki kewenangan lainnya sebagaimana dimaksud dalam undang-undang ini atau berdasarkan undang-undang lainnya. Notaris bagian dari negara yang memiliki kekuasaan umum dan berwenang menjalankan sebagian dari kekusaan negara untuk membuat alat bukti tertulis secara autentik dalam bidang hukum perdata.

Negara memberikan wewenang kepada notaris untuk memberikan pelayanan kepada masyarakat. Kewenangan Notaris berdasarkan Pasal 15 ayat (1) Undangundang No. 2 Tahun 2014 tentang Jabatan Notaris yakni berwenang membuat akta autentik mengenai semua perbuatan, perjanjian, dan penetapan yang diharuskan

16 Habib Adjie, Hukum Notaris Indonesia, Bandung: Rafika, 2008, Hlm. 8. 
oleh peraturan perundang-undangan dan/atau dikehendaki oleh yang berkepentingan untuk dinyatakan dalam akta autentik, menjamin kepastian tanggal pembuatan akta, menyimpan akta, memberikan grosse, salinan dan kutipan akta, sepanjang pembuatan akta itu tidak juga ditugaskan atau dikecualikan kepada pejabat lain atau orang lain yang ditetapkan oleh undang-undang.

Penyandang jabatan Notaris sangat bermartabat, mengingat peranan notaris penting bagi masyarakat. Perilaku dan perbuatan notaris dalam menjalankan jabatan profesinya harus sesuai dengan kode etik yang ditentukan oleh Ikatan Notaris Indonesia (I.N.I). Notaris memiliki etika profesi, dimana etika profesi merupakan etika moral yang khusus diciptakan untuk kebaikan jalannya profesi yang bersangkutan. ${ }^{17}$ Kebaikan yang dimaksud standar pelayanan notaris kepada masyarakat.

Notaris sebagai pejabat umumm diangkat oleh negara, tidak menerima honorariumm dari negara akann tetapi menerima honorarium atas jasa hukum yang diberikan sesuai dengan kewenangannya. Besarnya nilai honorairum yang diterima oleh Notaris pada Undang-undang No. 2 Tahun 2014 tentang Jabatan Notaris tidak diatur secara mutlak, melainkan disesuaikan dengan keadaan daerah masing-masing. Tidak menutup kemungkinan adanya kesepakatan menentukan honorarium antara Notaris dengan klien, sehingga tidak adanya kesamaan honorarium sesama Notaris.

Jasa hukum dii bidang kenotariatan dibutuhkan oleh setiap golongan masyarakat. Penggunaan jasa kenotariatan oleh masyarakat yang mampu dapat dilakukan dengan memberikan honorarium kepada notaris. Hal ini sebaliknya dengan golongan masyarakat tidak mampu, yakni

17 Sidharta, Moralitas Profesi Hukum Suatu Tawaran Kerangka Berpikir, Bandung: Refika Aditama, 2006, Hlm. 9. tidak dapat memberikan honorarium kepada notaris. Perbedaan kemampuan ekonomi mengakibatkan dampak pada penggunaan jasa notaris. Pada dasarnya notaris tidak boleh menolak setiap klien yang datang untuk melakukan perbuatan hukum di bidang kenotariatan sesuai Pasal 37 ayat (1) Undang-undang Nomor 2 Tahun 2014 tentang Jabatan Notaris. Pasal tersebut menunjukkan bahwa orang tidak mampu dapat diberikan jasa kenotariatan secara cuma-cuma.

Adanya Pasal 37 ayat (1) Undangundang No. 2 Tahun 2014 tentang Jabatan Notaris Negara menjamin semua hak warga negaranya tanpa terkecuali selama berada di Wilayah NKRI. Pernyataan tersebut secara tegas telah dinyatakan dalam Pasal 1 ayat (3) Undang-Undang Dasar Negara Republik Indonesia Tahun 1945. Indonesia sebagai negara hukum memiliki ciri khas. ${ }^{18}$ Setiap orang wajib dihormati, dijunjung tinggi dan dilindungi oleh Negara, sehingga memberikan rasa keadilan ketika seseorang melakukan perbuatan hukum.

Permasalahan honorarium merupakan hal yang pelik, karena Notaris membutuhkan materi dalam menjalankan kegiatannya. ${ }^{19}$ Pasal 37 ayat (1) Undangundang No. 2 Tahun 2014 tentang Jabatan Notaris harus dapat dilaksanakan oleh Notaris untuk memberikan hak atas orang tidak mampu.

Makna yang terkadung dalam Pasal 37 (1) Undang-undang No. 2 Tahun 2014 tentang Jabatan Notaris perlu diperjelas, meskipun adanya lampiran "penjelasan umum" dan dinyatakan jelas. Standar kualifikasi orang tidak mampu diperlukan penjelasan, agar dapat diimplementasikan. Norma hukum seharusnya berisi kenyataan normatif yang seharusnya dilakukan, sehingga dapat dilakukan tanpa menimbulkan multi persepsi pada Pasal 37

18 Kaelan, Achmad Zuabaidi., Pendidikan Kewarganegaraan, Yogyakarta: Paradigma, 2007, Hlm. 92.

${ }^{19}$ Wawancara dengan x., Notaris di Kabupaten Bogor, pada tanggal 15 April 2017. 
ayat (1) Undang-undang No. 2 Tahun 2014 tentang Jabatan Notaris.

Notaris terikat dan patuh pada peraturan yang mengatur jabatan Notaris yakni Undang-undang No. 2 Tahun 2014 tentang Jabatan Notaris. Peraturan perundang-undangan tersebut menjadi pedoman Notaris dalam menjalankan tugas dan kewajibannya, apabila melanggar akan mendapatkan sanksi. Notaris yang melanggar Pasal 37 ayat (1) Undangundang No. 2 Tahun 2014 tentang Jabatan Notaris, akan mendapatkan sanksi pada Pasal 37 ayat (2) Undang-undang Nomor 2 Tahun 2014 tentang Jabatan Notaris berisi "Notaris yang melanggar ketentuan sebagaimana dimaksud pada ayat (1) dapat dikenai sanksi berupa: a. Peringatan lisan; b. Peringatan tertulis; c. Pemberhentian sementara; d. Pemberhentian dengan hormat; atau e. Pemberhentian tidak hormat".

Sanksi merupakan sebuah bentuk harapan pemerintah, agar Notaris menjalankan Pasal 37 ayat (1) Undangundang No. 2 Tahun 2014 tentang Jabatan Notaris sesuai dengan ketentuan yang berlaku. Makna Pasal 37 ayat (1) Undangundang No. 2 Tahun 2014 tentang Jabatan Notaris sebagai penentu kualifikasi sanksi yang akan berikan kepada notaris. Kontradisi antara das sollen dan das sein disebabkan adanya perbedaan pandangan dan prinsip kepentingan hukum. Hukum menghendaki terpenuhinya hak-hak orang tidak mampu, bagi notaris keadaan tersebut merugikan karena honorarium notaris diperoleh dari klien.

Menyadari bahwa profesi notaris dibutuhkan dalam pembangunan, maka Pasal 37 ayat (1) Undang-undang No. 2 Tahun 2014 tentang Jabatan Notaris menunjukkan bahwa Notaris menjalankan profesi dalam memberikan perlindungan dan jaminan tercapainya kepastian hukum kepada masyarakat tanpa melihat kemampuan ekonomi kliennya. Pada Pasal 37 ayat (2) Undang-undang No. 2 Tahun 2014 tentang Jabatan Notaris sebagai pengawal pelaksanaan kinerja notaris pada pemberian jasa hukum dibidang kenotariatan secara cuma-cuma di masyarakat.

Kata makna dalam KBBI merupakan arti ataupun maksud perkataan. ${ }^{20}$ Pemberian makna pada setiap orang berbeda tergantung pada pemahaman masing-masing. Makna pada suatu objek, ditandai kesepakatan bersama untuk merujuk kata tersebut. Ilmu hukum yang memberikan kemanfaatan dan kepastian memandang bahwa makna dalam hukum harus ditafsirkan sama.

Kebutuhan jasa hukum di bidang kenotariatan dapat diberikan kepada masyarakat dan tidak mengenal status sosial, baik dari golongan masyarakat mampu atau masyarakat yang kurang mampu yang membutuhkan jasa hukum tersebut harus mendapatkan pelayanan yang sama dari seorang Notaris.

Seorang Notaris dalam memberikan jasa hukum kepada masyarakat kurang mampu sesuai dengan kewenangan yang diatur dalam Undang-undang No. 2 Tahun 2014 tentang Jabatan Notaris tidak diwajibkan menerima honorarium atau upah, tetapi dalam praktek notaris di Kabupaten Bogor khususnya klien yang datang untuk meminta jasa hukum di bidang kenotariatan secara cuma-cuma hanya ditemukan beberapa saja dan tidak semua notaris melayani pemberian jasa secara cuma-cuma.

Menurut responden narasumber yaitu notaris selama berpraktek belum ada ditemui klien yang datang tersebut bermaksud untuk meminta pemberian jasa hukum di bidang kenotariatan secara cuma-cuma, hal ini disebabkan karena pada umumnya klien yang datang tersebut bermaksud untuk membuatkan notaril akta mengenai pemindahan hak dan kewajiban antara para pihak mengenai suatu transaksi yang mempunyai nilai ekonomis seperti perjanjian sewa-menyewa, legalisir berkas, legalisasi, atau warmeking. Selain

20 Dendy Sugono, Kamus Bahasa Indonesia, Jakarta: Pusat Bahasa, 2008, Hlm. 903. 
itu klien ada juga yang datang ke kantor pada umumnya bermaksud untuk membuatkan suatu akta untuk pendirian Organisasi Masyarakat (ORMAS), Pendirian yayasan, Firma, atau bentuk mascap lainnya, maka dengan demikian klien yang datang tersebut tidak bisa dikatakan orang tidak mampu karena klien tersebut mempunyai harta kekayaan. ${ }^{21}$

Sehubungan wawancara penulis dengan responden notaris $\mathrm{x}$, selama berpraktek notaris di Kabupaten Bogor belum ada yang melayani pemberian jasa hukum di bidang kenotariatan kepada klien kurang mampu secara cuma-cuma, maka bentuk lain dari pemberian jasa hukum tersebut adalah berupa pengurangnan honorarium atau upah atas jasa notaris dalam membuatkan akta dimana besar honorarium Notaris tersebut telah ditentukan oleh Undang-undang Nomor 2 Tahun 2014 tentang Jabatan Notaris. Klien tersebut tidak bisa dikatakan orang yang tidak mampu karena mereka mempunyai harta kekayaan.

Berdasarkan hasil wawancara dengan responden notaris $\mathrm{x}$, mengatakan bahwa pengurangan harga atau honorarium Notaris diberikan jika klien tidak mampu membayar honorarium Notaris sesuai dengan jenis akta yang dibuatnya, maka notaris akan menanyakan seberapa sanggup klien tersebut untuk membayar honorarium sepenuhnya. ${ }^{22}$

Berdasarkan hasil penelitian yang penulis lakukan dengan 4 (empat) orang responden narasumber notaris yaitu $A, B$, $C$, dan notaris $D$, diperoleh keterangan bahwa dalam melaksanakan kewajibannya berdasarkan Undang-undang Nomor 2 Tahun 2014 tentang Jabatan Notaris menyangkut pemberian jasa hukum dibidang kenotariatan secara cuma-cuma pada masyarakat kurang mampu, dilatarbelakangi oleh 3 (tiga) faktor yaitu:

a. Faktor kemanusiaan.

\footnotetext{
${ }^{21}$ Ibid.

${ }^{22}$ Ibid.
}

b. Faktor keterusterangan klien yang menghadap kepadanya.

c. Faktor keyakinan notaris bahwa klien yang menghadap kepadanya memang tergolong orang kurang mampu.

Menurut responden notaris pada wawancara yang penulis lakukan mengatakan bahwa notaris memberikan jasa hukum secara cuma-cuma pada klien yang tergolong kurang mampu dapat berdasarkan atas keterus terangan klien tersebut, bahwa dia tidak mampu untuk membayar biaya jasa hukum dari notaris yang bersangkutan sehingga jasa hukum diberikan secara cuma-cuma.

Hal senada juga diungkapkan oleh responden notaris $\mathrm{x}$, pada wawancara penulis lakukan bahwa seorang notaris berdasarkan keyakinannya dapat menilai klien yang menghadap kepadanya patut diberikan pelayanan jasa hukum di bidang kenotariatan secara cuma-cuma bisa dilihat dari penampilan dan jenis jasa hukum apa yang ingin ia dapatkan dari notaris yang bersangkutan. Notaris tidak akan meminta syarat seperti surat keterangan dari instansi pemerintah seperti surat keterangan miskin atau tidak mampu kepada klien yang tidak mampu untuk mendapatkan pelayanan jasa hukum di bidang kenotariatan karena dengan meminta syarat tersebut menurut notaris akan memberatkan klien tersebut. ${ }^{23}$

Hasil wawancara penulis dengan responden Notaris $\mathrm{x}$, mengatakan selama ini dalam praktek memberikan jasa pada masyarakat kurang mampu seperti memberikan penyuluhan hukum atau ada yang datang berkonsultasi, tidak pernah dipungut biaya atau jasa yang diberikan karena niat notaris untuk membantu sesama. $^{24}$

Setiap melaksanakan kewenangan dan kewajiban untuk memberikan jasa hukum kepada klien, seorang notaris harus melakukan dengan profesional dalam arti bahwa kalau memang jasa hukum tersebut

\footnotetext{
${ }^{23} \mathrm{Ibid}$.

${ }^{24}$ Ibid.
} 
diberikan kepada klien tanpa memungut honorarium, maka notaris yang bersangkutan wajib melakukannya, tetapi kalau memang jasa hukum tersebut tidak bisa diberikan secara cuma-cuma, maka notaris harus menjelaskan alasannya kepada klien sehingga dapat dimengerti.

Berdasarkan hasil wawancara yang penulis lakukan dengan beberapa responden klien Notaris mengatakan:

1. Responden klien notaris yang berprofesi sebagai pemilik panti asuhan pada wawancara yang penulis lakukan yang mengatakan bahwa ia ingin membuatkan akta sewa-menyewa sebuah rumah untuk panti asuhannya tersebut tapi karena ia merasa tidak sanggup membayar sepenuhnya biaya pembuatan akta tersebut, maka Notaris hanya memberikan biaya atas pengurusan akta tersebut. ${ }^{25}$

2. Responden klien Notaris yang berprofesi sebagai pegawai swasta pada wawancara yang penulis lakukan yang mengatakan bahwa ia datang ke kantor Notaris ingin membuatkan akta perjanjian kredit, ia meminta pengurangan biaya pembuatan akta tersebut kepada Notaris dikarenakan ia merasa tidak sanggup membayar sepenuhnya biaya pembuatan akta tersebut. ${ }^{26}$

3. Responden klien keturunan tionghoa pada wawancara yang penulis lakukan yang mengatakan bahwa ia datang ke kantor Notaris ingin membuat akta perjanjian kawin, ia merasa mampu dan biaya pembuatan akta tersebut tidak memberatkannya, maka ia tidak meminta pengurangan biaya pembuatan akta tersebut. $^{27}$

Adapun penelitian yang penulis lakukan dengan menggabungkan hasil wawancara antara responden Notaris dan responden klien Notaris yang datang ke kantor Notaris yang pernah menggunakan jasa hukum di bidang kenotariatan

25 Wawancara dengan Bapak X, klien Notaris, Pada tanggal 15 April 2017.

${ }^{26}$ Ibid.

${ }^{27}$ Ibid. diperoleh keterangan bahwa ada beberapa faktor yang melatarbelakangi seorang notaris memberikan jasanya secara cumacuma pada klien yang tergolong mampu yaitu:

a. Notaris memberikan jasanya secara cuma-cuma pada klien yang tergolong masyarakat kurang mampu karena ada rasa jiwa sosial dan persaudaraan antar sesama.

b. Notaris memberikan jasanya secara cuma-cuma pada klien yang terggolong menengah karena merupakan rekan sejawat notaris atau masih keluarga.

c. Notaris memberikan jasanya secara cuma-cuma pada klien yang tergolong masyarakat yang mampu dikarenakan balas jasa atas pertolongan klien tersebut pada notaris yang bersangkutan.

Lembaga hukum saat ini telah menjadi bagian dari kebutuhan hukum masyarakat Indonesia untuk mendapatkan pelayanan jasa hukum dibidang kenotariatan menyangkut pembuatan akta autentik serta kewenangan lain yang tidak ditentukan oleh Undang-undang Nomor 2 Tahun 2014 tentang Jabatan Notaris.

Seorang notaris dalam menjalankan jabatannya dituntut untuk dapat menyesuaikan keahlian dan ketrampilan dengan perkembangan zaman yang mengakibatkan perkembangan kebutuhan hukum yang semakin rumit. Menurut arti dalam kamus, bahwa jabatan berati pekerjaan (tugas) dalam pemerintahan atau organisasi. ${ }^{28}$ Arti Jabatan seperti ini dalam arti yang umum untuk setiap bidang pekerjaan (tugas) yang sengaja dibuat untuk keperluan yang bersangkutan baik dan pemerintahan maupun organisasi yang dapat diubah sesuai dengan keperluan. Jabatan dalam arti sebagai Ambt ${ }^{29}$ merupakan fungsi, tugas, wilayah kerja

28 Departemen Pendidikan dan Kebudayaan, Kamus Besar Bahasa Indonesia, Jakarta: Balai Pustaka, 1994, Hlm. 392.

29 N. E. Algra, H.R.W.Gokkel dkk., Kamus Istilah Hukum Fockema Andreae, Belanda-Indonesia, Jakarta: Binacipta, 1983, Hlm. 159. 
pemerintah pada umumnya atau badan perlengkapan pada khususnya. Istilah atau sebutan jabatan merupakan suatu istilah yang dipergunakan sebagai fungsi atau tugas ataupun wilayah kerja dalam pemerintah. Selain itu Notaris dituntut untuk selalu siap melayani masyarakat diwilayah kerjanya.

Notaris wajib memberikan pelayanan hukum kepada masyarakat yang membutuhkan jasanya, dalam hal ini pelayanan jangan diartikan sempit seperti hanya membuat akta, melakukan legalisasi terhadap akta dibawah tangan, memberikan konsultasi/penyuluhan hukum yang menyangkut bidang kenotariatan melainkan juga menyangkut beberapa aspek mulai dari kemudahan masyarakat mendapatkan informasi tentang persyaratan untuk pembuatan akta otentik dan keramahan notaris beserta karyawannya dalam melayani klien yang smua itu merupakan sebagian dari aktivitas dalam menjalankan profesi notaris.

Pelayanan hukum dalam dunia kenotariatan harus tetap mengacu dan patuh pada Undang-undang Nomor 2 Tahun 2014 tentang Jabatan Notaris serta Kode Etik Notaris dengan tujuan agar dalam melaksanakan profesi notaris dilingkungan masyarakat tidak menurunkan harkat dan martabat serta keluhan profesi Notaris.

Berdasarkan uraian diatas tentunya dapat memberikan pemahaman tentang apa yang disebut pelayanan dan bagaimana proses pelayanan dalam menunjang kesuksesan kerja proses seorang Notaris. Kedudukan profesi Notaris sebagai pejabat umum dalam memberikan pelayanan hukum dibidang kenotariatan dapat juga diberikan secara cuma-cuma khususnya kepada klien yang tergolong masyarakat kurang mampu. Adapun penjelasan mengenai persyaratan untuk mendapatkan pelayanan secara cuma-cuma dari seorang notaris tidak diatur secara rinci dalam Undang-undang Nomor 2 Tahun 2014 tentang Jabatan Notaris.
Pasal 37 Undang-undang Nomor 2 Tahun 2014 tentang Jabatan Notaris yang isinya menjelaskan bahwa notaris wajib memberikan jasa hukum di bidang kenotariatan secara cuma-cuma pada orang tidak mampu, sehingga penerapan pasal tersebut dalam menjalankan profesinya tergantung Notaris yang bersangkutan yang dipengaruhi oleh faktor kemanusiaan, keterusterangan klien dan keyakinan notaris sendiri.

Berdasarkan Pasal 1 Undang-undang Nomor 36 Tahun 2008 tentang Pajak Penghasilan, $\mathrm{PPh}$ dikenakan terhadap subjek pajak atas penghasilan yang diterima atau diperolehnya dalam tahun pajak. Pada dasarnya subjek pajak $\mathrm{PPh}$ adalah orang pribadi dan badan. Dengan demikian, $\mathrm{PPh}$ orang pribadi (nature person) merupakan pajak atas penghasilan yang dikenakan terhadap wajib pajak badan (legal person) atas penghasilan yang diterima atau diperolehnya dalam tahun pajak. ${ }^{30}$

Berdasarkan ketentuan Pasal 1 undang-undang Nomor 36 Tahun 2008 tentang Pajak Penghasilan, setiap orang pribadi sebagai subjek pajak mempunyai kemungkinan (potensi) diwajibkan membayar pajak. Kemungkinan itu menjadi pasti atau baru terjadi jika terhadap mereka kedapatan objeknya (sasarannya), yaitu penghasilan. Dipenuhinya syarat sebagai subjek pajak merupakan kewajiban pajak subjektif, sedangkan dalam hal seseorang sudah menerima atau memperoleh penghasilan pada suatu tahun pajak berarti dipenuhinya kewajiban pajak objektif.

Pengenaan PPh didasarkan pada dua syarat, yaitu subjek pajak dan objek pajak. Dengan perkataan lain, untuk benar-benar menjadi wajib pajak, harus memenuhi syarat subjektif dan syarat objektif. Subjek

\footnotetext{
${ }^{30}$ Bastari, Analisis Pengaruh Kenaikan Penghasilan Tidak Kena Pajak Terhadap Penerimaan Pemerintah dan Perekonomian Daerah dalam Rangka Pengembangan Wilayah Kota Medan, Disertasi, Pascasarjana USU, 2011, HIm. 15.
} 
pajak baru dapat dikenakan PPh apabila ada objek pajaknya yaitu penghasilan.

Subjek Pajak diartikan sebagai orang yang dituju oleh undang-undang untuk dikenakan pajak. Pajak Penghasilan dikenakan terhadap subjek pajak berkenaan dengan penghasilan yang diterima atau diperolehnya dalam Tahun Pajak. $^{31}$ Subjek pajak yang menerima atau memperoleh penghasilan tersebut disebut sebagai Wajib Pajak (WP).

Meskipun subjek pajak menurut undang-undang Nomor 36 Tahun 2008 tentang Pajak Penghasilan terdiri dari orang pribadi, warisan yang belum terbagi sebagai satu kesatuan menggantikan yang berhak, Badan, Bentuk Usaha Tetap (BUT), namun pada hakikatnya hanya ada dua subjek pajak yaitu orang pribadi dan badan. Warisan yang belum terbagi sebagai satu kesatuan menggantikan yang berhak pada akhirnya akan bermuara kepada subjek pajak orang pribadi, sedangkan BUT pada akhirnya akan bermuara pada orang pribadi atau badan.

Subjek Pajak Orang Pribadi adalah Orang pribadi yang bertempat tinggal di Indonesia atau orang pribadi yang berada di Indonesia lebih dari 183 (seratus delapan puluh tiga) hari dalam jangka waktu 12 (dua belas) bulan, atau orang pribadi yang dalam suatu tahun pajak berada di Indonesia dan mempunyai niat untuk bertempat tinggal di Indonesia.

Pada prinsipnya orang pribadi yang menjadi subjek pajak dalam negeri adalah orang pribadi yang bertempat tinggal atau berada di Indonesia. Termasuk dalam pengertian orang pribadi yang bertempat tinggal di Indonesia adalah mereka yang mempunyai niat untuk bertempat tinggal di Indonesia. Niat untuk bertempat tinggal di Indonesia ditimbang menurut keadaan. Keberadaan orang pribadi di Indonesia lebih dari 183 (seratus delapan puluh tiga) hari tidaklah harus berturut-turut, tetapi ditentukan oleh jumlah hari orang tersebut berada di Indonesia dalam jangka waktu 12

31Waluyo, Op.Cit, Hlm. 89. (dua belas) bulan sejak kedatangannya di Indonesia. ${ }^{32}$

Sedangkan orang pribadi yang tidak bertempat tinggal di Indonesia, orang pribadi yang berada di Indonesia tidak lebih dari 183 (seratus delapan puluh tiga) hari dalam jangka waktu 12 (dua bulan) bulan, dan badan yang tidak didirikan dan tidak bertempat kedudukan di Indonesia, yang menjalankan usaha atau melakukan kegiatan melalui bentuk usaha tetap di Indonesia.

Mulainya kewajiban pajak subjektif subjek pajak dalam negeri orang pribadi adalah sejak orang pribadi lahir, berada, atau berniat tinggal di Indonesia. Terhadap orang pribadi yang berada lebih dari 183 (seratus delapan puluh tiga) hari dalam jangka waktu 12 (dua belas) bulan. Kewajiban pajak subjektifnya mulai timbul pada hari pertama berada di Indonesia. berakhirnya kewajiban pajak subjektif subjek pajak dalam negeri orang pribadi adalah pada saat meninggal dunia atau meninggalkan Indonesia untuk selamalamanya. ${ }^{33}$

Objek PPh adalah penghasilan. Menurut Pasal 4 ayat (1) (seratus delapan puluh tiga), "Yang dimaksud dengan penghasilan adalah setiap tambahan kemampuan ekonomis yang diterima atau diperoleh baik dari Indonesia maupun dari luar Indonesia yang digunakan baik untuk investasi maupun konsumsi atau untuk menambah kekayaan Wajib Pajak yang bersangkutan, dengan nama dan dalam bentuk apapun". ${ }^{34}$ Dilihat dari mengalirnya (inflow) tambahan kemampuan ekonomis kepada WP, penghasilan dikelompokkan atas pekerjaan (employment income), kegiatan, usaha (business income), modal (capital income), dan penghasilan lain-lain (other income). Dilihat dari penggunaannya

\footnotetext{
${ }^{32}$ Anastasia, Op.Cit, Hlm. 167.

${ }^{33}$ Gunadi, Panduan Komprehensif Pajak Penghasilan, jakarta: PT Multi Guna Consultindo, 2010, Hlm. 3.

${ }^{34}$ Pajak Penghasilan, http://id.wikipedia.org/wiki/Pajak_penghasilan, Diakses pada tanggal 15 April 2017.
} 
(outflow) penghasilan bisa dipakai untuk konsumsi dan ditabung untuk menambah kekayaan. Semua jenis penghasilan harus digabungkan untuk mendapatkan tax base dan kerugian dikompensasikan (kompensasi horizontal). Definisi penghasilan tersebut merupakan definisi secara konseptual, sedangkan untuk memahami definisi penghasilan secara operasional harus dilihat pada contohcontoh penghasilan yang diberikan oleh Pasal 4 ayat (1) Undang-undang Nomor 36 Tahun 2008 tentang Pajak Penghasilan tersebut.

Salah satu contoh penghasilan yang tercantum dalam Pasal 4 ayat (1) butir a Undang-undang Nomor 36 Tahun 2008 tentang Pajak Penghasilan adalah penggantian atau imbalan berkenaan dengan pekerjaan atau jasa yang diterima atau diperoleh termasuk gaji, upah, premi asuransi jiwa dan premi asuransi kesehatan yang dibayar oleh pemberi kerja, tunjangan, honorarium, komisi, bonus, gratifikasi, uang pensiun, atau imbalan dalam bentuk lainnya, termasuk imbalan dalam bentuk natura yang pada hakikatnya merupakan penghasilan, kecuali ditentukan lain dalam UU PPh.

\section{KESIMPULAN}

Berdasarkan hasil penelitian dan pembahasan di atas, penulis dapat mengambil kesimpulan sebagai berikut:

1. Social responsibility profesi notaris yang dilaksanakan terhadap lembaga pendidikan dan keagamaan pondok pesantren berdasarkan latar belakang bahwa melihat realita banyaknya pondok pesantren yang berdiri di daerah Kabupaten Bogor dan DKI Jakarta namun belum memiliki akta pendirian sehingga untuk mendapatkan bantuan dari pemerintah setempat mendapatkan kesulitan. Sehingga dengan adanya akta notaris dan bantuan hukum kepada pondok pesantren di Kabupaten Bogor dan DKI Jakarta dapat membantu pondok pesantren.
Hasil dari Social responsibility profesi notaris yaitu pondok pesantren memiliki akta pendirian pondok pesantren, menerima bantuan hukum, terbantu dalam proses mendapatkan bantuan sosial dari pemerintah Provinsi Jawa Barat dan DKI Jakarta.

2. Pembayaran pajak penghasilan dari praktek Social Responsibility Notaris di Kabupaten Bogor dan DKI Jakarta dilakukan menggunakan sistem self assessment. Dalam pelaksanaanya, sistem ini megajarkan notaris untuk patuh dan mandiri dalam melaksanakan kewajiban pajak, dengan langkah-langkah sebagai berikut: a) Membuat pencatatan; b) Melakukan perhitungan pajak penghasilan dengan metode perhitungan Neto; dan c) Melaksanakan pelunasan dan pelaporan pajak penghasilan.

3. Kebijakan tentang tax deductible adalah suatu kebijakan pemerintah berdasarkan peraturan direktur jenderal pajak dan Pasal 6 UU PPh, untuk notaris yang memberikan jasa selaku pribadi dalam praktek social responsibility notaris yang tidak memungut biaya akta atau honorarium dari klien yang mendirikan yayasan pondok pesantren secara online atau tidak dikenakan potongan pajak penghasilan sesuai tarif berdasarkan Undang-undang Pajak Penghasilan. Dimana penghasilan brutonya yang diterima notaris bersifat akumulatif selama setahun.

\section{SARAN}

1. Sebaiknya social responsibility profesi notaris lebih ditingkatkan supaya pondok pesantren memiliki akta pendirian pondok pesantren, menerima bantuan hukum, dan terbantu dalam proses mendapatkan 
bantuan sosial dari pemerintah Provinsi Jawa Barat dan DKI Jakarta.

2. Disarankan ada aturan pelaksana tersendiri terkait perhitungan honorarium seorang notaris sebagai penjabaran dari Pasal 36 Undangundang tentang Jabatan Notaris dan tidak disamakan dengan ketentuan yang ada di dalam Undang-undang tentang Pajak Penghasilan, terkait ketentuan yang berkaitan dengan pekerjaan bebas yang di dalamnya mengatur tax deductible dalam hal Corporate Social Responsibility (CSR).

3. Sebaiknya kebijakan tax deductible dapat dipertimbangkan pemerintah dalam upaya membantu kegiatan sosial seperti pendirian yayasan pondok pesantren salafiah yang non profit.

\section{UCAPAN TERIMA KASIH}

\section{DAFTAR PUSTAKA}

\section{Buku:}

Anwar Borahima, Kedudukan Yayasan di Indonesia (Eksistensi, Tujuan dan Tanggung Jawab Yayasan), Jakarta: Prenada Media, 2010.

Asrohah, Pelembagaan Pesantren Asal-usul dan Perkembangn Pesantren di Jawa.

Bastari, Analisis Pengaruh Kenaikan Penghasilan Tidak Kena Pajak Terhadap Penerimaan Pemerintah dan Perekonomian Daerah dalam Rangka Pengembangan Wilayah Kota Medan, Disertasi, Pascasarjana USU, 2011.

Dendy Sugono, Kamus Bahasa Indonesia, Jakarta: Pusat Bahasa, 2008.

Departemen Pendidikan dan Kebudayaan, Kamus Besar Bahasa Indonesia, Jakarta: Balai Pustaka, 1994.

Dohack Latief, Ekonomi Global, Surabaya: Muhammadiyah University Press, 2000.

Gatot Supramono, Hukum Yayasan di Indonesia, Jakarta: Rineka Cipta, 2008.

Gunadi, Panduan Komprehensif Pajak Penghasilan, jakarta: PT Multi Guna Consultindo, 2010.

Habib Adjie, Hukum Notaris Indonesia, Bandung: Rafika, 2008.

Kaelan, Achmad Zuabaidi., Pendidikan Kewarganegaraan, Yogyakarta: Paradigma, 2007.

Komar Andasasmita, Notaris Dengan Sejarah, Peranan, Tugas Kewajiban, Rahasia Jabatannya, Bandung: Sumur, 1981.

, Notaris I : Peraturan Jabatan, Kode Etik dan Asosiasi Notaris/Notariat, Ikatan Notaris Indonesia Daerah Jawa Barat, Bandung, 1991. 
Mulhadi, Hukum Perusahaan Bentuk-bentuk Badan Usaha di Indonesia, Bogor: Ghalia Indonesia, 2010.

N. E. Algra, H.R.W.Gokkel dkk., Kamus Istilah Hukum Fockema Andreae, Belanda-Indonesia, Jakarta: Binacipta, 1983.

Nurcholis Madjid, Bilik-bilik Pesantren: Sebuah Potret Perjalanan, Jakarta: Paramadina, 1997.

Sidharta, Moralitas Profesi Hukum Suatu Tawaran Kerangka Berpikir, Bandung: Refika Aditama, 2006.

Wahjoetomo, Perguruan Tinggi Pesantren, Jakarta: Gema Insani Persada, 1997.

\section{Peraturan Perundang-undangan}

Undang-undang Dasar 1945.

Undang-undang Nomor 28 Tahun 2004 tentang Yayasan.

Undang-undang Nomor 2 Tahun 2014 tentang Jabatan Notaris.

Undang-undang Nomor 36 Tahun 2008 tentang Pajak Penghasilan. 